\title{
Development of standard classification tool for chronic pain and its clinical application
}

\author{
Takahiro Ushida ${ }^{1}$, Shigeki Yamaguchi ${ }^{2}$, Yoshiyuki Kimura ${ }^{2}$, and Shuichi Aono ${ }^{3}$ \\ ${ }^{1}$ Multidisciplinary Pain Center, Aichi Medical University School of Medicine \\ ${ }^{2}$ Department of Anesthesiology, Dokkyo Medical University, School of Medicine \\ ${ }^{3}$ Department of Pain Data Management, Aichi Medical University School of Medicine
}

\begin{abstract}
Chronic pain is a biological psychosocial pathological condition, which is caused by various elements involved in many ways. Therefore, it is necessary to analyze the disease state from various viewpoints and to treat multimodally. Since there was no standard diagnostic tool for chronic pain so far, it was difficult to develop epidemiological research and development and evaluation of treatment in accordance with specific pathological conditions. Therefore, the IASP proceeded development to add the item of Chronic Pain in ICD-11, which was officially announced from WHO in June 2018. This attempts to classify chronic pain into seven major categories (1) chronic primary pain, (2) chronic cancer related pain, (3) chronic postoperative and posttraumatic pain, (4) chronic secondary musculoskeletal pain, (5) chronic secondary visceral pain, (6) chronic neuropathic pain, (7) chronic secondary headache and/or orofacial pain) and others.

By developing a more realistic method of using this new standard disease name, effective utilization not only in research but also in clinical practice is needed. In addition, this review will also introduce the versions that the Chronic Pain Research Group of the Ministry of Health, Labor and Welfare has been developing. At the same time as disease name classification, it is important to know where and how to treat chronic pain.

In 2017, IASP defined the treatment by forming "Task Force on Multimodal Pain Treatment Defines Terms for Chronic Pain Care" in order to unify the names of confused treatment modes. At the same time as disease name classification, it is important to know where and how to treat chronic pain. Also, in the past, IASP has been defining treatment facilities such as Multidisciplinary Pain Center. In addition, this time we will introduce the assessment of O-P factor which is helpful for thinking about what kind of patients and where to receive medical treatment.
\end{abstract}

Keywords

ICD-11; Chronic pain; Multidisciplinary pain treatment; Interdisciplinary pain treatment 


\author{
長引く痛みの克服に向けて : \\ 慢性疼痛の分類 (ICD-11) や治療モード, 治療施設などの分類と臨床利用 \\ 牛田 享宏 $1 /$ 山口 重樹 $2 /$ 木村 嘉之 $2 /$ 青野 修一 3 \\ 1 愛知医科大学 医学部 学際的痛みセンター \\ 2 獨協医科大学 医学部 麻酔科ペインクリニック \\ 3 愛知医科大学 医学部 疼痛データマネジメント寄附講座
}

\footnotetext{
はじめに

感覚としての痛みが組織傷害の警告信号とし て働くことは否定し得ない事実であり，急性疼 痛の役割として理解されている。一方, 長引く 痛み“慢性疼痛”について, IASP では 3 力月以 上続く痛みとして定義している。これらは何ら かの要因 $(※) て ゙$ 痛みが長引くことなどで, 患者 は行動 (疼痛行動) を引き起こすなどして, こ れらが更に症状を悪化・持続させる要因となっ てしまうような病態である。何らかの要因 $(※)$ には骨・関節・筋などの障害, 神経そのものの 障害だけでなく，精神心理的な要因（およびそ れに大きく関与する養育歴や就労環境なども含 めた社会的な背景など）も含まれることになる。 同時に, 慢性疼痛においての“痛み”は警告信号 としての意義が変容しているケースも多い。し たがって実際の慢性疼痛診療においては様々な 要因を多角的, 多面的に診断 (分析) し, 更に ゴールを設定して，治療を進めていく必要があ る。一方, 現在の一般的な縦割り診療の中では これらの病態に有効に対峙できないケースも多 くある。これらは患者自身の苦痛だけでなく医 療経済的にも課題が多いことから厚生労働省で は 2010 年に“今後の慢性の痛み対策について (提言)”を作成し ${ }^{2}$, 痛みセンターの構築や地
}

域ネットワーク事業など様々な対策を進めてき ている。その中では, どのような慢性疼痛に対 してどのような治療をすれば有効性が得られる のか? という議論が為されることになる。実際 にその課題を克服するためには慢性疼痛を適切 に評価・分類して, 適した治療施設で適切な治療 方策 (治療モードなど) で対応していく必要が ある。そこで今回は現在までIASP を中心に進 められてきた慢性疼痛のコーディング ICD-11 や厚生労働省の慢性の痛み政策研究班（慢性の 痛み診療・教育の基盤となるシステム構築に関 する研究班）の取り組みについて述べる。

\section{慢性疼痛の分類としての WHO の ICD-11 分類の開発}

慢性疼痛状態の診断については, 現在まで 用いられてきているWHOの国際疾病分類 (ICD-10) にも診断コードがいくつか含まれて いる。しかし，これまでの診断分類では疫学的 な面を反映しておらず，体系的に分類されてい ない。また，ICD における適切に評価するため のコーディングがないことで, 慢性疼痛に関す る正確な疫学データの取得が困難になり, 適切 な疼痛治療位置づけや医療費の適切化, 新しい 治療法の開発および実施を妨げることにもなっ 
ている。そのため, IASP では Treede 元理事長 らを中心に Presidential Task Force を構成し, 次期 ICD-11 に対応するための慢性疼痛の分類 の研究開発活動を進めてきた。開発においては, 慢性疼痛が, 部位 (頭痛など)・病因（癌など）・ 病態 (神経障害性疼痛) が混在する上に，これ らの分類の原則に適合しにくい慢性疼痛（線維 筋痛など）がある中で，様々な夕イプの慢性疼 痛に適合でき，一般的な ICD-11 のフレームに 適合するものを作成することを課題として作成 されている3)。

今回, 2018 年 6 月に WHO から正式リリー スされた ICD-11 に記載された慢性疼痛として の分類は, 慢性疼痛 MG-30 の下に,

(1) MG30.0 慢性一次疼痛 (例：過敏性腸症候 群, 非特異的慢性腰痛, 線維筋痛)

(2) MG30.1 慢性癌関連疼痛 (例: 慢性癌疼痛, 慢性化学療法後疼痛)

(3) MG30.2 慢性術後および外傷後疼痛 (例： 切断後の慢性疼痛, 火傷後の慢性疼痛)

(4) MG30.3 慢性二次筋骨格疼痛 (例: 持続性 炎症による慢性筋骨格疼痛，変形性関節症 に関連する慢性筋骨格疼痛）

(5) MG30.4 慢性二次内臓痛（例：持続性炎症 または血管機構からの慢性内臟痛）

(6) MG30.5 慢性神経障害性疼痛 (例: 慢性疼 痛性多発神経障害, 慢性中枢後脳梗塞)

(7) MG30.6 慢性二次性頭痛または口顔面痛 (例 : 慢性口顔面筋肉痛)

(8) MG30.Y その他の特異性のある慢性疼痛

(9) MG30.Z 慢性疼痛 (分類不能) である。

この下に小分類（子カテゴリー）があるので WHO からコーディングッールのサイトがある ので参照いただきたい (https://icd.who.int/ct11_ 2018/icd11_mms/en/release\#/)。
なお，ICD-11 の多層分類の開発にあたって は同じ診断が 1 つ以上の親カテゴリーに包含さ れることも可能にすることとしている。すなわ ち各診断 (子カテゴリー) は 1つの親カテゴリー として保持するが, 別の 2 目の親カテゴリー として持つこともできる。例としては “慢性の 化学療法後疼痛” は 1 つの親カテゴリーとして 慢性癌性疼痛と別の親カテゴリーとして慢性神 経障害性疼痛を持つことができることとしてい る。

(1) MG30.0 慢性一次疼痛 (例：過敏性腸症候 群, 非特異的慢性腰痛, 線維筋痛)

3 カ月以上持続または再発し, 有意な感情的 苦痛または有意な機能障害 (日常生活の活動へ の干渉抢よび社会的役割への干渉）に関連し， 説明困難な 1 つ以上の解剖学的領域に打ける疼 痛である。別の慢性疼痛分類によって説明でき ないものであり，多くの病因が不明な慢性疼痛 のために作成された現象学からの定義である。 筋骨格または神経障害性疼痛に同定されていな い腰痛, 慢性的な広範な疼痛, 線維筋痛および 過敏性腸症候群などの一般的な症状がここに分 類される。なお，疼痛を引き起こす生物学的知 見については存在していてもよい。

(2) MG30.1 慢性癌関連疼痛 (例: 慢性癌疼痛, 慢性化学療法後疼痛)

原発癌自体または転移（慢性癌疼痛）または その治療 (慢性癌後疼痛)によって引き起こさ れる疼痛である。それは, 併存する疾病によっ て引き起こされる疼痛とは異なる。痛みが，が んやその治療に起因する可能性は非常に高いも のがこの項目に入るものであり, その起源が瞹 昧な場合は, 慢性一次疼痛のセクションでの コードとする。 
(3) MG30.2 慢性術後および外傷後疼痛（例： 切断後の慢性疼痛, 火傷後の慢性疼痛) 慢性の術後および外傷後の痛みは, 外科処置 または組織損傷 (火傷を含む任意の外傷を伴う) を受けて治癒過程を超えて，すなわち手術また は組織外傷の少なくとも 3 力月後にも持続する 疼痛である。痛みは, 手術野または傷害領域に 局在する，あるいはその領域にする神経の神経 支配領域にまで分布するか，またはデルマトー ムに分布する。（手術/外傷による深部体性感覚 または内臓組織への損傷）と呼ばれる。感染, 悪性腫瘍などの痛みの他の原因, 既存の疼痛の 問題から継続する疼痛は除外する必要がある。 手術の種類によっては慢性術後および外傷後疼 痛はしばしば神経障害性疼痛であり得る。神経 障害のメカニズムが重要であっても, この項目 にカテゴリー付ける。痛みの術後または外傷後 の病因が非常に考えられるものをこの項目に入 れるべきである。

(4) MG30.3 慢性二次筋骨格疼痛（例：持続性 炎症による慢性筋骨格疼痛, 変形性関節症 に関連する慢性筋骨格疼痛）

関節, 骨, 筋肉, 脊柱, 腱および関連軟部 組織における持続的侵害受容に由来する慢性 疼痛状態であり, 局所および全身の病因を伴 うが, 哚部体性感覚組織病変にも関連する。痛 みは自発的であっても運動による誘発であっ てもよい。痛みが内臓病変に関連している場 合は, 慢性内臓痛の診断が適切かどうかを検 討する。また神経障害のメカニズムに関連す る場合, 慢性神経障害性疼痛の下でコードす る。なお，痛みのメカニズムが非特異的であ る場合, 慢性的な筋骨格痛は慢性一次疼痛の 下でコードする。急性疼痛 (MG31), 慢性神経 因性疼痛 (MG30.5), 慢性一次性疼痛 (MG30.0),
慢性二次内臓痛 (MG30.4) は除外する。

(5) MG30.4 慢性二次内臓痛（例：持続性炎症 または血管機構からの慢性内臓痛）

慢性内臓痛は, 頭頸部領域および胸部, 腹部 および骨盤腔の内藏器官に由来する持続性また は再発性疼痛である。痛みの内臓病因は非常に 有望であるべきである；漠然としている場合は， 慢性一次疼痛のセクションでコードを使用する ことを検討する。神経障害性疼痛 (8E43.0) は除 外する。

(6) MG30.5 慢性神経障害性疼痛 (例 : 慢性疼 痛性多発神経障害, 慢性中枢後脳梗塞)

体性感覚神経系の病変または疾患によって引 き起こされる慢性疼痛である。疼痛は, 自発痛 もしくは痛みを伴う刺激に対する応答の増大 (痛覚過敏) または通常は非疼痛性の刺激（アロ ディニア）に対する痛みとして誘発され得る。 慢性神経因性疼痛の診断には, 神経系の障害 (傷害)または疾患の病歴および痛みの神経学的 に妥当な分布が重要である。体性感覚神経系の 関与を示唆する脱落所見（例えば，感覚の低下 または脱失) や感覚症状・徵候（例えば，異痛症 または痛覚過敏)は，障害された神経の神経支 配領域と適合しなければならない。なお，三叉 神経痛 (8B82.0), ヘルペス後神経痛 (1E91.5)， 幻肢痛 (8D8A.01) についてはコード化にあたつ て別項目とする。

\section{(7) MG30.6 慢性二次性頭痛または口顔面痛}

(例 : 慢性口顔面筋肉痛)

慢性の二次的な頭痛および顔面痛は，原因を 頭蓋部に有するものであり, 少なくとも 3 カ月

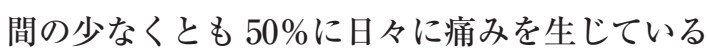
ものである。1日あたりの疼痛の持続時間は, 
How to classify chronic pain, where and how to treat it

少なくとも 4 時間 (未治療) であるか，または 1 日あたり数回のより短い激痛が生じる。病因が 曖昧な場合は, 慢性一次疼痛のセクションで コードを使用することを検討する。なお，二次 性頭痛 (8A84), 頭部への外傷性損傷に起因する 急性頭痛 (8A84.0), 頭部への外傷性損傷に起因 する持続性頭痛 (8A84.1), 頭頸部損傷に起因す る頭痛 (8A84.Y)，頭蓋骨または澒椎の血管内頭 蓋障害に起因する頭痛 (8A84.Y), 非血管性の頭 蓋内障害に起因する頭痛 (8A84.Y), ホメオス夕 シスの障害に起因する頭痛 (8A84.Y)，顔面また は首の障害に起因する頭痛または顔面痛 (8A84.Y)，物質に起因する頭痛 (8A84.Y)，薬 物離脱による頭痛 $(8 \mathrm{~A} 84 . \mathrm{Y})$, 薬物乱用頭痛 (8A84.Y) は別項目とする。

\section{コーディングのフィールドテストと 診療研究での利用}

厚生労働研究班では IASP の ICD-11 開発の Presidential Task Force の要請もあり，協働して 2016 年に ICD-11 のフィールドテストを行っ た1）。フィールドテスト協力者は予めWHO の ICD-11 テストサイトで訓練を行い，コーディ ングに参加した。その結果，多くの患者は，慢 性一次性疼痛または慢性二次筋骨格疼痛のいず れかとしてコードされた。コード化された 507 人の患者のうち, $3.0 \%$ がカテゴリーに合致しな い慢性疼痛を有し，20.1\%が複数の診断コード が付けられけた。技術的な理由でダブルコー ディングを調整した後， $2.0 \%$ 症例がカテゴ リーに入れることができなかった。個々の症例 について ICD-11 コーディングの有用性を 0 (全くない)，1 (多少有用)，2 (非常に有用)，3 (完全に有用)に点数つけした結果では平均の有 用性は $1.9 \pm 1.0$ であった。また，診断の確信度
について同様に個々の症例について0（全く確 信がない), 1 (多少), 2 (非常に) ３ (完全に確 信がある)で調べたところ平均は $2.0 \pm 1.0$ で あった。これまで, 慢性疼痛が単に 3 力月以上 続く痛みという定義しかなく, 臨床面から科学 的なアプローチしていくッールがなかった中に おいて今回の ICD-11 の慢性疼痛のコーディン グのッールの開発は非常に意味が大きいと考え られる。

\section{ICD-11の利用に向けて （臨床現場や研究への応用）}

実際にこのコーディングを疫学的な研究を超 えて, 特定の慢性疼痛の病態の改善の評価（治 療の有用性評価など）に使用するにあたっては, 痛みの病因，痛みの発症維持の基盤にある病態 生理や心理社会背景，部位などを考慮した上で カテゴリー付けていく必要がある。厚生労働研 究班では ICD-11 に本邦での実臨床に則した項 目付や詳細を加えて番号を付記した ICD-11J (仮)を試案として作成してきている(附 1$)$ 。こ こでは, chronic widespread pain (MG30.01)の 中で，狭義の fibromyalgia を MG30.01a，それ には合致しないものを other chronic widespread pain (MG30.01y), chronic widespread pain, unspecified (MG30.01z) というふうに分類できる ようにしている。今後, 慢性疼痛のレジストリ の開発（慢性の痛み政策研究事業: 研究代表 牛 田享宏, 委員長 山口重樹) に向けて, 改良を加 えていく予定である。

\section{慢性疼痛診療のモードや治療にあたる 施設の定義について}

慢性疼痛の診療においては，複雑な病態に対 
応するために様々な治療が行われる。しかし， その治療にあたっては多角的な分析を行い，診 断しゴールを設定して治療にあたっていく必要 があることから治療の方法や施設の形態につい ても用語を明文化する必要がある。

治療介入の方法の定義について IASP のタス クフォース (2017) では,

- Unimodal Treatment (単一性の治療) : 特定の 一つの疼痛メカニズムまたは痛みの診断に向 けられた単一の治療的介入と定義される。例 えば，理学療法士による運動療法のみ。

・ Multimodal Treatment（マルチモーダル治 療)：単一診療家（科）による異なる疼痛機序 の治療を目的に, 別の治療的介入を同時に行 うこととして定義される。例えば，医師によ る疼痛管理のためのプレガバリンおよびオピ オイドの使用，医師による疼痛管理のための NSAID および装具の使用など。

- Multidisciplinary Treatment：異なる分野の治 療者によって提供されるマルチモーダル治療 と定義されている。例えば，医師による抗う つ薬の処方, 理学療法士からの運動治療と心 理士による認知行動療法介入を同時に行うこ とである。すべての医療専門家は独自の患者 への治療目的の達成のために作業し, 必ずし も互いに連携する必要はない。

- Interdisciplinary Treatment : 生物心理社会モ デルの考え方とゴールを共有して, 多職種の チームが評価と治療を協力して行うマルチ モーダル治療と定義される。例えば，医師に よる抗うつ薬の処方, 理学療法士からの運動 治療と心理士による認知行動療法介入を同時 に行い，定期的なチームミーティングなどで， 診断合意, 治療目標治療とレビューの計画を 進めるもの。

としている。
疼痛診療にあたる施設について IASP のタス クフォース (Pain Clinic Guidelines 2009 年, Pain Treatment Services 2009 年) がカテゴリー を作成し，ペインクリニックや学際的 (集学的) 痛みセンターなどの内容や役割を言及している。

学際的（集学的）痛みセン多一 (Interdisciplinary Pain Center*) については急 性打よび慢性疼痛の患者ケアおよびそれに関連 する研究，指導を行う医療従事者㧍よび基礎科 学者の組織であり, 施設は医学部または教育病 院の構成要素として存在することが望ましいと している。また，その理想的な形としては慢性 疼痛の身体的, 心理社会的, 医療的, 職業的, 社会的側面を評価し，治療することができる 様々な医療提供者 (医師, 看護師, 心理学者, 理学療法士, 作業療法士, 職業カウンセラー, ソーシャルワーカーなど）をスタッフに抱えて いるべきであり，3つの医学的専門分野を代表 する医師がいることが望ましく，医師の 1 人が 精神科医でない場合，2つの専門医および臨床 心理士が最低限の要件とされる。診療は器質的 側面および心理社会的側面の両方を評価し，治 療することができなければならず，医療従事者 は個々の患者の事象と診療プログラムの両方に ついて，定期的に打互いに連絡を取り合う必要 があるとしている。またセンターは慢性疼痛に 関する研究を実施しているべきであり, 学部生, 大学院生，および博士後レベルを含む，幅広い

※英文に扔いては2009 年の段階では Interdisciplinary Pain Center に相応するもの が Multidisciplinary Pain Center という名前で 用いられ定義として使われているが，2017の 方向性から集学的（学際的）痛みセンター= Interdisciplinary Pain Center として上記では 記載した。なお, 今後日本語においても集学 的と学際的の明確な定義付けが必要になるも のと考えられる。 
種類の医療提供者の教育プログラムで活発に活 動する必要があるとしている。

\section{実臨床にあたっての診療施設の役割分担や 連携のためのツール}

今後, 慢性疼痛の診療において集学的（学際 的）痛みセンターが果たすべき役割は重要であ るが，一方で人口の 15～20\%もいるとされる慢 性疼痛患者に対応するためには施設内でのプラ イマリ・ケア医や整形外科，脳神経外科，内科, 麻酔科・ペインクリニック医などとの連携と地 域連携が必須の課題である。

\section{O-P 要因ツール}

どのような施設がどのような立場で慢性疼痛 に対峙していく必要があるのかを考えるために, 独自の O (Organic) - P (Psychosocial) 要因の軸 を用いた対応施設分類を作成し，患者の分析を ICD-11 と同時に進めている (Fig.1)4)。O 要因 の軸 (器質的な要因に対応すべき施設のレベル), $\mathrm{P}$ 要因の軸（精神心理的な要因に対峙すべき施 設のレベル）の 2 つの軸を作り，いずれもレベ ル $0=$ 医療として介入する必要がないもの，レ ベル $1=$ プライマリ・ケア (もしくは非専門医) で対応すべきもの，レベル $2=$ 専門医がクリ ニックなどで介入すべきもの， レベル $3=$ 専門 医がチーム（病院など）で対応すべきもの，レ ベル $4=$ 専門医が対応しても困難と考えられる ものとして，分類を進めてきている。例として は, 器質的な軸 $(\mathrm{O}$ 要因 $)=0$ で精神心理的な軸 $(\mathrm{P}$ 要因 $)=2$ であれば，精神科医や心療内科が 単科で対応すべきものとなる。また, $\mathrm{O}$ 要因 $\mathrm{P}$ 要因ともに 3 ということになると集学的痛みセ ンターが診療にあたるべきとなる。

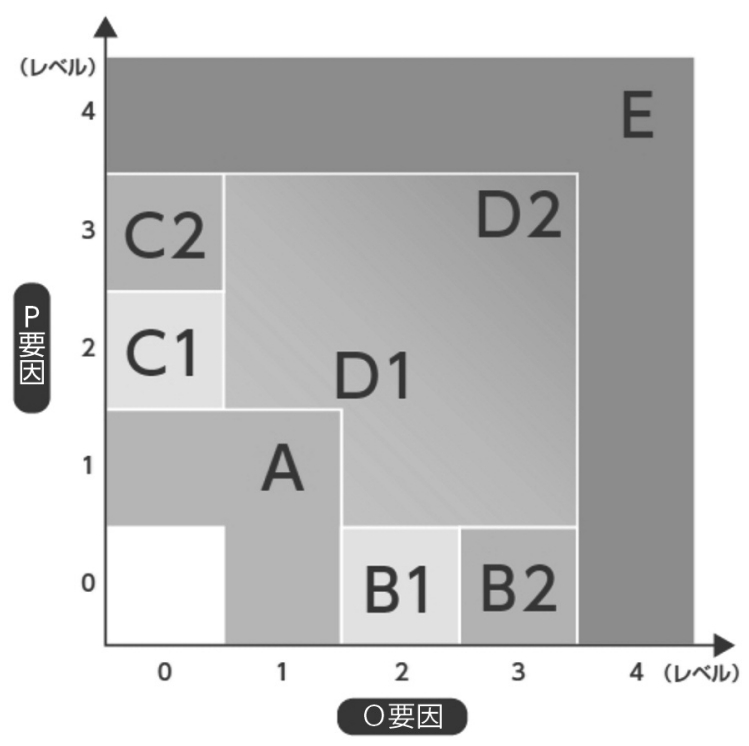

\footnotetext{
○要因：精神心理など、症状と不鈎り合いになる要因への対応レベル

$P$ 要因：器質的要因への対応レベル

レベル0:ないor臨床上問題にならない程度

レベル 1 : プライマリ·ケア医(もしくは非專門医)が対応できる レベル 2 : 専門医(クリニック)の介入が必要

レベル 3 : 総合病院などで専門医による高度な治療・管理が必要

レペル 4 : 専門医でも対応困難、多少の改善しか見込めない
}

A : プライマリ•ケア医(もしくは非専門医)
B1 : 器質的疾患を取り扱うクリニック
B 2 : 器質的疾患を取り扱う高度医療機関
C1 : 精神心理的疾患を取り扱うクリニック
C2 : 精神心理的疾患を取り扱う高度医療機関
D1 : 複数の専門家の介入が必要
D2 : 専門家同士の密に連携した介入が必要
E : 専門家が連携し、社会的問題への対応も含めた介入が必要

Fig.1 O-P 要因ツール

（文献 4 より引用改変）

このような評価法を使って患者の病態病因を 考えた上での診療施設の役割分担を進める必要 があると考えられる。

\section{おわりに}

慢性疼痛は生物心理社会的な病態であり， 様々な要素が複合的に大きく絡んで生じるもの である。そのため多角的に分析して， multimodal に治療を進めることが求められる。現在, 
慢性疼痛に対して標準診断名がなかったことか ら IASP では ICD-11を開発し, WHO から 2018 年 6 月に正式発表されている。これにより, 疫学的な研究やより病態に沿った治療の開発や その評価が可能になるものと考えられる。加え て, その他の疼痛評価法の開発導入を進めるこ とで, 病態が明確化されればより確度の高い適 切な治療やゴール設定が可能になると考えられ る。また，同時に O-P 要因の評価などが用い られていくことで多職種連携，地域医療連携が 進めやすくなることが考えられる。一方で, 慢 性疼痛は心理・社会的な側面が非常に大きく, 医療が介入できない面も大きいのも事実である。 患者自らでなければ変われない（変わらない) 部分については，これまで述べた評価法などの 結果を踏まえて, 自分の状態 (痛みの強さや日 常生活状況など）を患者が自ら把握して, 治療 を進める必要がある。現在, 厚生労働研究班で は患者が持つ携帯端末などで計測して見える化 するアプリ (モバイルマイカ) を開発してきて いるが5)，それを医療者と患者が共に使うこと で自ら変わる足がかりになればとも考える。

\section{文 献}

1) Barke, A., Korwisi, B., Casser, H.R., Fors, E.A., Geber, C., Schug, S.A., Stubhaug, A., Ushida, T., Wetterling, T., Rief, W., Treede, R.D., Pilot field testing of the chronic pain classification for ICD11: the results of ecological coding, BMC Public Health 18 (2018) 1239.

2）厚生労働省「慢性の痛みに関する検討会」. 今 後の慢性の痛み対策について (提言), 2010.

3) Treede, R.D., Rief, W., Barke, A., Aziz, Q., Bennett, M.I., Benoliel, R., Cohen, M., Evers, S., Finnerup, N.B., First, M.B., Giamberardino, M.A., Kaasa, S., Kosek, E., Lavand'homme, P., Nicholas, M., Perrot, S., Scholz, J., Schug, S., Smith, B.H., Svensson, P., Vlaeyen, J.W., Wang, S.J., A classification of chronic pain for ICD-11, Pain, 156 (2015) 1003-1007.

4) 牛田享宏, 連載：「こじらせ疼痛」にどう向き 合う 第 1 回 総論 原因不明の慢性痛, その原 因は医師の思考停止，日経メディカル Online, 2018.6.20.

5) http://mobilemaica.com.

Address for correspondence: Takahiro Ushida Multidisciplinary Pain Center,

Aichi Medical University School of Medicine 1-1 Yazako-Karimata, Nagakute, Aichi 480-1195, Japan

附 1

\begin{tabular}{|c|c|}
\hline 1 & ※ マークのついている診断コードは筆者による \\
\hline \multirow[t]{4}{*}{1.1} & Chronic widespread pain (MG30.01) \\
\hline & 1.1.1 Fibromyalgia (MG30.01a)※ \\
\hline & Other chronic widespread pain (MG30.01y)※ \\
\hline & Chronic widespread pain, unspecified (MG30.01z)※ \\
\hline \multirow[t]{5}{*}{1.2} & Complex regional pain syndrome (8D8A.0) \\
\hline & 1.2.1 Complex regional pain syndrome type 1 (8D8A.00) \\
\hline & Complex regional pain syndrome type 2 (8D8A.01) \\
\hline & Other specified complex regional pain syndrome (8D8A.0Y) \\
\hline & 1.2.z Complex regional pain syndrome, unspecified (8D8A.0Z) \\
\hline \multirow[t]{8}{*}{1.3} & Chronic primary headache and orofacial pain (MG30.03) \\
\hline & 1.3.1 Chronic migraine (8A80.2) \\
\hline & Chronic tension-type headache (8A81) \\
\hline & Trigeminal autonomic cephalalgias (TACs) (8A82) \\
\hline & Chronic temporomandibular disorder pains (MG30.03a)※ (DA0E.8) \\
\hline & Chronic burning mouth (DA0F.0) \\
\hline & Chronic primary orofacial pain (MG30.03b)※ (MG30.03) \\
\hline & Atypical facial pain (8B82.1) \\
\hline
\end{tabular}


1.3.y Other chronic specified primary headache and orofacial pain (MG30.03y)※

1.3.z Chronic primary headache and orofacial pain, unspecified (MG30.03z)※

1.4 Chronic primary visceral pain (MG30.00)

1.4.1 Primary (functional) chest pain (MG30.00a)※

1.4.2 Epigastric pain syndrome (MG30.00b) ※

1.4.3 Irritable bowel syndrome (MG30.00c)※

1.4.4 Chronic primary abdominal pain syndrome (MG30.00d)※

1.4.5 Bladder pain syndrome (MG30.00e) ※

1.4.6 Chronic pelvic pain (MG30.00f) $\%$

1.4.6.1 Chronic pelvic pain in females (MG30.00f1)※

1.4.6.2 Chronic pelvic pain in males (MG30.00f2)※

1.4.y Other specified chronic primary visceral pain (MG30.00y)※

1.4.z Chronic primary visceral pain, unspecified (MG30.00z)※

1.5 Chronic primary musculoskeletal pain other than orofacial (MG30.02)

1.5.1 Chronic primary low back pain (MG30.02a)※

1.5.2 Chronic primary cervical pain (MG30.02b)※

1.5.3 Chronic primary thoracic pain (MG30.02c)※

1.5.4 Chronic primary limb pain (MG30.02d)※

1.5.y Other specified chronic primary musculoskeletal pain other than orofacial (MG30.02y)※

1.5.z Chronic primary musculoskeletal pain other than orofacial, unspecified (MG30.02z)※

1.y Other specified chronic primary pain (MG30.0Y)

1.z Chronic primary pain, unspecified (MG30.0Z)

$2 \quad$ Chronic cancer related pain (MG30.1)

2.1 Chronic cancer pain (MG30.10)

2.1.1 Chronic visceral pain from cancer [secondary parent: Chronic visceral pain] (MG30.10a)※

2.1.2 Chronic bone cancer pain (Bone and Bone Marrow metastasis) (2E03)

2.1.3 Chronic neuropathic cancer pain [secondary parent: Other chronic neuropathic pain]

2.2 Chronic post cancer treatment pain (MG30.11)

2.2.1 Chronic post-chemotherapy pain

2.2.1.1 Chronic painful chemotherapy-induced polyneuropathy [secondary parent: Chronic peripheral neuropathic pain]

2.2.1.x Other chronic post-chemotherapy pain

2.2.1.z Chronic post-chemotherapy pain, unspecified

2.2.2. Chronic post-radiotherapy pain

2.2.2.1 Brachial plexopathy [secondary parent: Chronic neuropathic pain after peripheral nerve injury]

2.2.2.2 Painful lumbosacral plexopathy [secondary parent: Chronic neuropathic pain after peripheral nerve injury]

2.2.2.x Other chronic post-radiotherapy pain

2.2.2.z Chronic post-radiotherapy pain, unspecified

2.y Other specified chronic cancer related pain (MG30.1Y)

2.z Chronic cancer related pain, unspecified (MG30.1Z)

3 Chronic postsurgical and posttraumatic pain (MG30.2)

3.1 Chronic postsurgical pain (MG30.21)

3.1.1 Chronic pain after amputation (MG30.21a)※

3.1.2 Chronic pain after spinal surgery (MG30.21b)※

3.1.3 Chronic pain after thoracotomy (MG30.21c)※

3.1.4 Chronic pain after breast surgery (MG30.21d)※

3.1.5 Chronic pain after cholecystectomy (MG30.21e)※

3.1.6 Chronic pain after herniotomy (MG30.21f)※

3.1.7 Chronic pain after hysterectomy (MG30.21g) ※

3.1.y Other specified chronic postsurgical pain (MG30.2Y)

3.1.z Chronic postsurgical pain, unspecified (MG30.2Z)

3.2 Chronic posttraumatic pain (MG30.20) 
3.2.1 Chronic pain after amputation (MG30.21a)※

3.2.2 Chronic pain after burns injury (MG30.20b) ※

3.2.3 Chronic pain after peripheral nerve injury (MG30.20c)※

3.2.4 Chronic pain after central nervous system injury (MG30.20d) ※

3.2.4.1 Complex regional pain syndrome type 2 [Primary parent: primary chronic pain] (8D8A.01)

3.2.5 Whiplash injury associated pain disorders

[secondary parent: Headache attributed to trauma or injury to the head and/or neck] (MG30.20e)※, Strain or sprain of cervical spine (NA23.4)

3.2.5.1 Whiplash associated disorder with complaint of neck pain, stiffness or tenderness only (NA23.40)

3.2.5.2 Whiplash associated disorder with complaint of neck pain with musculoskeletal signs (NA23.41)

3.2.5.3 Whiplash associated disorder with complaint of neck pain with neurological signs (NA23.42)

3.2.6 Chronic pain after musculoskeletal injury

[secondary parent: Chronic musculoskeletal pain associated with structural changes] (MG30.20f)※

3.2.6.1 Chronic musculoskeletal pain following bone fractures

3.2.6.2 Chronic posttraumatic arthritis

3.2.y Other specified chronic posttraumatic pain (MG30.2Y)

3.2.z Chronic posttraumatic pain unspecified (MG30.2Z)

$4 \quad$ Chronic neuropathic pain (MG30.5)

4.1 Chronic peripheral neuropathic pain (MG30.51)

4.1.1 Trigeminal neuralgia (8B82.0)

4.1.2 Chronic neuropathic pain after peripheral nerve injury (MG30.51b)※

4.1.2.1 Neuropathic post-amputation pain [secondary parent: Chronic pain after amputation]

4.1.3 Painful polyneuropathy (MG30.51c)※

4.1.4 Postherpetic neuralgia (但し postherpetic polyneuropathy (1E91.5))

4.1.5 Painful radiculopathy (8B93p)※ (8B93=radiculopathy)

4.1.6 Chronic peripheral neuropathic pain after vascular disorder/disease (MG30.51f) ※

4.1.y Other chronic peripheral neuropathic pain (MG30.51y)※

4.1.z Chronic peripheral neuropathic pain, unspecified (MG30.51z)※

4.2 Chronic central neuropathic pain (MG30.50)

4.2.1 Central neuropathic pain associated with spinal cord injury

[secondary parent: Chronic pain after central nervous system injury] (MG30.50a)※

4.2.2 Central neuropathic pain associated with brain injury

[secondary parent: Chronic pain after central nervous system injury] (MG30.50b)※

4.2.3 Central post-stroke pain (MG30.50c)※

4.2.4 Central neuropathic pain associated with multiple sclerosis (MG30.50d)※

4.2.5 Central neuropathic pain associated with vascular disorder (MG30.50e)※

4.2.y Other chronic central neuropathic pain (MG30.50y) ※

4.2.z Chronic central neuropathic pain, unspecified (MG30.50z)※

4.y Other chronic neuropathic pain (MG30.5Y)

4.z Chronic neuropathic pain, unspecified (MG30.5Z)

$5 \quad$ Chronic secondary headache and/or orofacial pain (MG30.6)

5.1 Headache/orofacial pain attributed to trauma or injury to the head and/or neck

(8A84.1 \& 8A84.Y \& MG30.60)

5.2 Headache/orofacial pain attributed to cranial or cervical vascular disorder (8A84.Y \& MG30.60)

5.3 Headache/orofacial pain attributed to non-vascular intracranial disorder (8A84.Y \& MG30.60)

5.4 Headache/orofacial pain attributed to a substance or its withdrawal (8A84.Y \& MG30.60)

5.5 Headache/orofacial pain attributed to infection (8A84.Y \& MG30.60)

5.6 Headache/orofacial pain attributed to disorders of homoeostasis or their nonpharmacological treatment (8A84.Y \& MG30.60)

5.7 Headache/orofacial pain attributed to disorder of the cranium, neck, eyes, ears, sinuses, salivary glands, oral mucosa (8A84.Y \& MG30.60)

5.8 Headache/orofacial pain attributed to mental and behavioral disorder

5.9 Chronic dental pain (MG30.61) 
How to classify chronic pain, where and how to treat it

5.10 Chronic headache/orofacial neuropathic pain (MG30.62)

5.10.1 Trigeminal Neuralgia [primary parent: Chronic peripheral neuropathic pain] (8B82.0)

5.10.2 Other cranial neuralgias (8B87)

5.10.x Other chronic headache/orofacial neuropathic pain (MG30.6Y)

5.10.z Chronic headache/orofacial neuropathic pain, unspecified (MG30.6Z)

5.11 Headache/orofacial pain attributed to chronic secondary temporomandibular disorders (MG30.63)

5.11.1 Chronic orofacial muscle pain

5.11.2 Chronic secondary temporomandibular joint pain (DA0E.8)

5.11.x Other headache/orofacial pain attributed to chronic secondary temporomandibular disorders (MG30.63)

5.11.z Headache/orofacial pain attributed to chronic secondary temporomandibular disorders, unspecified (MG30.63)

5.x Other chronic secondary headache and/or orofacial pain (MG30.6Y)

$5 . z \quad$ Chronic secondary headache and/or orofacial pain, unspecified (MG30.6Z)

$6 \quad$ Chronic secondary visceral pain (MG30.4)

6.1 Chronic visceral pain from persistent inflammation (MG30.42)

6.1.1 Chronic visceral pain from persistent inflammation in the head/neck region

6.1.2 Chronic visceral pain from persistent inflammation in the thoracic region

6.1.3 Chronic visceral pain from persistent inflammation in the abdominal region

6.1.4 Chronic visceral pain from persistent inflammation in the pelvic region

6.1.x Other chronic visceral pain from persistent inflammation

6.1.z Chronic visceral pain from persistent inflammation, unspecified

6.2 Chronic visceral pain from vascular mechanisms (MG30.41)

6.2.1 Chronic visceral pain from vascular mechanisms in the head/neck region

6.2.2 Chronic visceral pain from vascular mechanisms in the thoracic region

6.2.3 Chronic visceral pain from vascular mechanisms in the abdominal region

6.2.4 Chronic visceral pain from vascular mechanisms in the pelvic region

6.2.x Other chronic visceral pain from vascular mechanisms

6.2.z Chronic visceral pain from vascular mechanisms, unspecified

6.3 Chronic visceral pain from mechanical factors (MG30.40)

6.3.1 Chronic visceral pain from obstruction/distension in the head/neck region

6.3.2 Chronic visceral pain from obstruction/distension in the thoracic region

6.3.3 Chronic visceral pain from obstruction/distension in the abdominal region

6.3.4 Chronic visceral pain from obstruction/distension in the pelvic region

6.1.x Other chronic visceral pain from persistent inflammation

6.1.z Chronic visceral pain from persistent inflammation, unspecified

6.x Other specified chronic secondary visceral pain (MG30.4Y)

6.z Chronic secondary visceral pain, unspecified (MG30.4Z)

$7 \quad$ Chronic secondary musculoskeletal pain (MG30.3)

7.1 Chronic musculoskeletal pain from persistent inflammation (MG30.30)

7.1.1 Chronic musculoskeletal pain from persistent inflammation due to infection (MG30.30a)※

7.1.2 Chronic musculoskeletal pain from persistent inflammation due to crystal deposition (MG30.30b)※

7.1.3 Chronic musculoskeletal pain from persistent inflammation due to autoimmune disorders (MG30.30c)※

7.1.4 Chronic musculoskeletal pain from persistent inflammation due to enthesopathy (MG30.30d)※ Spinal enthesitis (FA92.00)

Enthesopathies of lower limb (FB54)

Certain specified enthesopathies (FB55)

Bursitis related to use, overuse or pressure (FB50.1)

7.1.5 Chronic musculoskeletal pain from persistent inflammation due to periarthritis (eg. frozen shoulder) (MG30.30e)※

7.1.y Other chronic musculoskeletal pain from persistent inflammation (MG30.30y)※ 
7.1.z Chronic musculoskeletal pain from persistent inflammation, unspecified (MG30.30z)※

7.2 Chronic musculoskeletal pain associated with structural changes (MG30.31)

7.2.1 Chronic musculoskeletal pain associated with osteoarthritis (MG30.31a)※

7.2.2 Chronic musculoskeletal pain associated with spondylosis (MG30.31b)※

7.2.3 Chronic pain after musculoskeletal injury [primary parent: Chronic posttraumatic pain] (MG30.31c)※

7.2.4 Chronic musculoskeletal pain associated with vascular disease/disorder (MG30.31d)※

7.2.y Other specified chronic musculoskeletal pain associated with structural changes (MG30.31y)※

7.2.z Chronic musculoskeletal pain associated with structural changes, unspecified (MG30.31z) ※

7.3 Chronic musculoskeletal pain associated with a disease of the nervous system (MG30.32)

7.3.1 Chronic secondary musculoskeletal pain associated with Parkinson's disease (MG30.32a)

7.3.2 Chronic secondary musculoskeletal pain associated with multiple sclerosis (MG30.32b)

7.3.3 Chronic secondary musculoskeletal pain associated with peripheral neurologic disease (MG30.32c)

7.3.y Other specified chronic musculoskeletal pain associated with a disease of the nervous system (MG30.32y)※

7.3.z Chronic musculoskeletal pain associated with a disease of the nervous system, unspecified (MG30.32z)※

7.y Other specified chronic secondary musculoskeletal pain (MG30.3Y)

7.z Chronic secondary musculoskeletal pain, unspecified (MG30.3Z)

Other chronic pain (MG30.Y)

Chronic pain, unspecified (MG30.Z) 